East African Journal of Science, Technology and Innovation, Vol. 2 (4): September 2021

This article is licensed under a Creative Commons license, Attribution 4.0 International (CC BY 4.0)

\title{
Characterization and pathogenicity of symbiotic bacteria associated with entomopathogenic nematode: Steinernema species KALRO
}

\author{
${ }^{1 *}$ NGUGI C N., ${ }^{2}$ WACHIRA P M., ${ }^{3}$ MBAKA J N., ${ }^{2 O K O T H ~ S ., ~}{ }^{2 M A N G U A ~ P ~ W ~}$
}

\author{
${ }^{1}$ Kenya Agricultural and Livestock Research Organization (KALRO), Horticulture Research Institute (HRI) P.O. Box 220-01000, \\ Thika \\ ${ }^{2}$ University of Nairobi, Kenya P.O. Box 30197-0100, Nairobi \\ ${ }^{3}$ Kenya Agricultural and Livestock Research Organization (KALRO), Horticulture Research Institute (HRI) P.O Box 220-01000, \\ Thika \\ ${ }^{*}$ Corresponding author: ceciliahngugi20@gmail.com
}

\begin{abstract}
The soil inhibiting entomopathogenic nematodes (EPNs), in the family Steinernematidae and Heterorhabditidae, are useful insect biological control agents. They have been used in the management of economically important crop pests. The EPNs are mutually associated with symbiotic bacteria genus Xenorhabdus and Photoharbdus respectively. The study aimed to isolate, characterize and evaluate the pathogenicity of symbiotic bacteria associated with EPN Steinernema sp. Kalro (Accession MW151701). The EPN Steinernema sp. Karlo was multiplied using the insect baiting technique. Its bacteria symbiont was isolated and characterized based on microscopic, biochemical, and physiological features like Gram staining, urease, motility test, and glucose fermentation test). Molecular identification and phylogenetic analysis were performed on $16 \mathrm{~S}$ rDNA nucleotide sequence. Pathogenicity of the bacteria isolate was evaluated against Tuta absoluta larvae with mortality data recorded after 24 and 48hours of exposure to the bacterial cell suspension. The bacteria were found to be motile and glucose fermentation positive. Sequence analysis of $16 \mathrm{~S}$ rDNA region resulted in $1500 \mathrm{bp}$ sequence with maximum similarity of between 97 and $98.93 \%$, with Xenorhabdus spp Accessions from Genbank. It closely matched to Xenorhabdus sp. My8NJ with $98.93 \%$ similarity (Accession AB507811.1). Mean percent larval mortality of $68 \pm 4.9$ and $88 \pm 8.0$ in the lowest cell suspension was observed in 24 and $48 \mathrm{~h}$ of exposure. It's concluded that, the symbiotic bacteria associated with Steinernema sp. Kalro is Xenorhabdus sp. strain Kalro Genbank Accession MW245845. The bacteria is a potential biological control agent against Tuta absoluta larvae. Further classification of the bacteria to species level and pathogenicity trials in the screen house and field are recommended.
\end{abstract}

Keywords: Entomopathogenic nematodes; Steinernema sp.; Kalro; Xenorhabdus sp.; strain Kalro, Pathogenicity; Tuta absoluta

Received: $\quad 11 / 02 / 21$

Accepted: $\quad 25 / 08 / 21$

Published: $\quad 25 / 09 / 21$

Cite as: Ngugi et al., (2021) Characterization and pathogenicity of symbiotic bacteria associated with entomopathogenic nematode: Steinernema species KALRO. East African Journal of Science, Technology and Innovation 2(4).

\section{Introduction}

Entomopathogenic nematodes (EPNs) in Steinernematidae and Heterorhabditidae families are soil-inhabiting soft non-segmented roundworms, are lethal against economically important crop pests (Aiswarya et al., 2017; CruzMartinez et al., 2017). In the free-living non- 
feeding stage of EPNs, the infective juveniles (IJ) infect insects by penetrating through body orifices and cuticles. The EPNs Steinernema and Heterorhabditis species are symbiotically associated with pathogenic bacteria species Xenorhabdus and Photorhabdus respectively (Ferreira \& Malan, 2014; Kalia et al., 2014; Abdolmaleki et al., 2016; Salgado-Morales et al., 2019). These bacteria belong to the family Enterobacteriaceae in the gamma subdivision of proteobacteria (Sangeetha et al., 2016; SalgadoMorales et al., 2019). The Xenorhabdus bacteria inhabit the bacterial vesicle of Steinernema while Photorhabdus are found in the gut of Heterorhabditis EPNs. Once the IJs invade an insect, the pathogenic bacteria are released from the intestines into the hemocoel of the host insect (Dillman \& Sternberg, 2012; Ferreira \& Malan, 2014; Abdolmaleki et al., 2016; Aiswarya et al., 2017). The bacteria multiply as the EPNs nourish on them and insect tissue and reproduce killing the insect host within 24-48 h (Shapiro-Ilan et al., 2015; Ulug et al., 2015). The symbiont bacteria provide pathogenicity, degrade and break down host tissues and suppress the immunity of the host during which the EPN reproduce and complete the growth cycle. The bacteria also produce antibiotics and enzymes in addition to toxins. The mutualism of bacteria and EPNs is vital as it inhibits the development of resistance in the host pest (Proschak et al., 2011; Poinar and Grewal, 2012; Dillman \& Sternberg, 2012; Kalia et al., 2014). Different EPNs harbor specific bacterial symbiont which is believed to dictate the virulence of the vector nematode. Biochemical, phenotypic, and DNA analysis have been used in the identification of bacteria. Recently, 16S rDNA sequencing and phenotypic evaluation have also been used in the characterization and identification of new bacteria species (Salvadori et al., 2012; Sangeetha et al., 2016; Ahmed et al., 2018). This study aimed at determining the identity of symbiotic bacteria associated with indigenous EPN Steinernema sp. Karlo, through biochemical and molecular methods.

\section{Materials and Methods}

Isolation of bacteria from infective juveniles of entomopathogenic nematode Steinernema sp.
Karlo and hemolymph of Galleria mellonella larvae

Symbiotic bacteria from entomopathogenic nematode (EPN) Steinernema sp. Karlo (Accession MW151701), was isolated from infective juveniles (IJs) according to Akhurst, (1980). The IJs were picked, crushed and a loopful of the macerated material was inoculated in LuriaBertani (LB) broth (10 g Bacto-Tryptone, $5 \mathrm{~g}$ Bacto-Yeast extract, and $10 \mathrm{~g} \mathrm{NaCl}$ in a litre of distilled water) and plates with NBTA media. Ten replications were made for each media and incubated for $48 \mathrm{~h}$ at $35^{\circ} \mathrm{C}$.

Galleria mellonella larvae were infected with EPN Steinernema sp. Karlo and bacteria associate isolated according to Woodring \& Kaya, (1988). A third segment from the head of G. mellonella was cut and the hemolymph streaked onto nutrient agar and NBTA plates using a sterile wire loop. The plates were incubated for $48 \mathrm{~h}$ at $35^{\circ} \mathrm{C}$ for bacteria growth. Sub culturing was done until colonies of the same size and morphology were obtained. For short-term storage (three-four months) the bacterium was maintained on nutrient agar plates at $28^{\circ} \mathrm{C}$ and liquid broth at $4^{\circ} \mathrm{C}$.

\section{Morphological and biochemical analysis of bacteria isolated on different media}

The bacterial phenotypic and biochemical assessments were done according to the Kumar et al., (2011) method.

\section{Gram Staining}

A small drop of distilled water was placed on a sterile slide. A loop full of the inoculum of bacteria isolate was scooped from colonies on NBTA media and spread thinly on the slide. The smear was heat fixed by passing the slide over a flame 3 times. The smear was flooded with Crystal violet stain for $1 \mathrm{~min}$, washed in distilled water, Gram's iodine was added, let to stand for $1 \mathrm{~min}$, and washed off. The smear was decolorized using acetone counterstained with Safranin for $3 \mathrm{~min}$, rinsed with distilled water, air-dried, and observed under the microscope (Leica DM 500), at x100 objective with oil immersion.

Symbiotic bacteria growth on differential media A loopful of pure bacteria isolate culture was 
streaked on Nutrient agar (NA), NBTA, and MacConkey media. Uninoculated plates were used as negative controls (-ve). All the media plates were incubated for 3 days at $35{ }^{\circ} \mathrm{C}$ and observed for bacterial growth and colony characteristics (shape, color, margins).

Glucose fermentation (Acid gas production) test Acid and gas production tests were done using glucose broth $(0.015 \mathrm{~g}$ Bromocresol Purple, $10 \mathrm{~g}$ glucose, $5 \mathrm{~g}$ Sodium chloride, and 1lt distilled water $)$. Sterile glucose broth $(10 \mathrm{ml})$ was dispensed in test tubes with Durham's tubes. The broth was inoculated with a loopful of bacteria isolate. Gas production and medium color change observed

\section{Motility test}

Semi-solid NA media which had been prepared at half strength was inoculated with bacteria isolate culture by a single stab at the center half depth of the tube using a sterile straight wire after which it was observed for motility (cloudiness).

\section{Catalase test (Slide test)}

Symbiotic bacteria isolate $(0.5 \mathrm{ml}), 24 \mathrm{hr}$ old inoculum was placed on a clean sterile dry glass slide using a sterile loop. A drop of freshly prepared $3 \%$ Hydrogen peroxide $\left(\mathrm{H}_{2} \mathrm{O}_{2}\right)$ was added and mixed with the inoculum. The setup was observed for a catalase (fizzling) reaction. To avoid false-positive catalase results, a wooden stick was used instead of a metal loop.

\section{Urease test}

Urease broth and slants containing Phenol red indicator were inoculated with a loopful of $36 \mathrm{hr}$ old bacterial culture. The setup was incubated for $48 \mathrm{~h}$ to 7 days at $35^{\circ} \mathrm{C}$ and medium color change was observed.

\section{Bacterial DNA extraction}

Total genomic DNA was extracted from fresh bacterial cultures $(24 \mathrm{~h}$ ) grown in Nutrient broth and Nutrient agar (NA plates). The bacteria suspension $(1 \mathrm{ml})$ was centrifuged for $5 \mathrm{~min}$ at $14000 \mathrm{rpm}$, the supernatant was decanted and TE buffer (Tris $1.0 \mathrm{~m}$ and EDTA $0.5 \mathrm{~m}$ ), $500 \mu \mathrm{l}$ was added. Equal amounts of $500 \mu \mathrm{l}$ of lysis buffer were added and sample mixtures were incubated in a water bath at $37^{\circ} \mathrm{C}$ for $30 \mathrm{~min}$. Phenol Chloroform Isoamyl (25:24:1 w/v) alcohol $500 \mu \mathrm{l}$ and centrifuged for $10 \mathrm{~min}$ at $14000 \mathrm{rpm}$ after which Absolute ethanol, of $500 \mu \mathrm{l}$ was added and the samples were incubated for $30 \mathrm{~min}$ at $-20^{\circ} \mathrm{C}$. The samples were then centrifuged for $10 \mathrm{~min}$ at $14000 \mathrm{rpm}$ to pellet the DNA, the supernatant discarded, $1000 \mu \mathrm{l}$ of wash buffer (95\% alcohol) added, and the sample mixture centrifuged for 5 $\mathrm{min}$ at $14000 \mathrm{rpm}$. The samples were air-dried for $40 \mathrm{~min}$. The DNA was resuspended in $10 \mu \mathrm{TAE}$ buffer (Sambrook et al., 1989; Weisburg et al., 1991; Chen \& Kuo, 1993). The presence of genomic DNA was determined by gel electrophoresis. The genomic DNA was sent to Biotech Inqabar South Africa for PCR using forward (27f-AGAGTTTGATCATGGCTCAG) and reverse (1492r-ACGGGCGGTGTGTGC), (Weisburg et al., 1991). The PCR conditions were $94^{\circ} \mathrm{C}$ for $5 \mathrm{~min}, 94^{\circ} \mathrm{C}$ for $3 \mathrm{~min}, 50^{\circ} \mathrm{C}$ for $1 \mathrm{~min}$, $68^{\circ} \mathrm{C}$ for $1 \mathrm{~min}$ and $68^{\circ} \mathrm{C}$ for $10 \mathrm{~min}$ holding at hold at $4^{\circ} \mathrm{C}$.

\section{Bacteria isolate sequence analysis}

The sequence editing and alignment were done using BioEdit Sequence Alignment Editor and MUSCLE on SeaView version 4 Alignment and Analysis program. A similarity search of the Genbank database was then done using the Basic Local Alignment Search Tool (BLAST) at https://blast.ncbi.nlm.nih.gov. to identify the bacteria isolate. The best BLAST hits obtained were retrieved and their sequences aligned using the SeaView alignment tool (Hall, 1999; Edgar, 2004; Gouy et al., 2010). In addition, BLAST Pairwise sequence alignment of the isolate bacteria sequence and the closest accession at NCBI (https://www.ncbi.nlm.nih.gov/) was done.

Phylogenetic analysis of symbiotic bacteria isolate The retrieved 16S rDNA sequences were used in phylogenetic tree reconstructed using the Neighbour-Joining method on SeaView program version 4 (Edgar, 2004; Gouy et al., 2010). Bootstrap analyses were performed with 1000 replications at a $70 \%$ threshold for relatedness. Bacteria Escherichia coli (J01859) was used as an outgroup. 


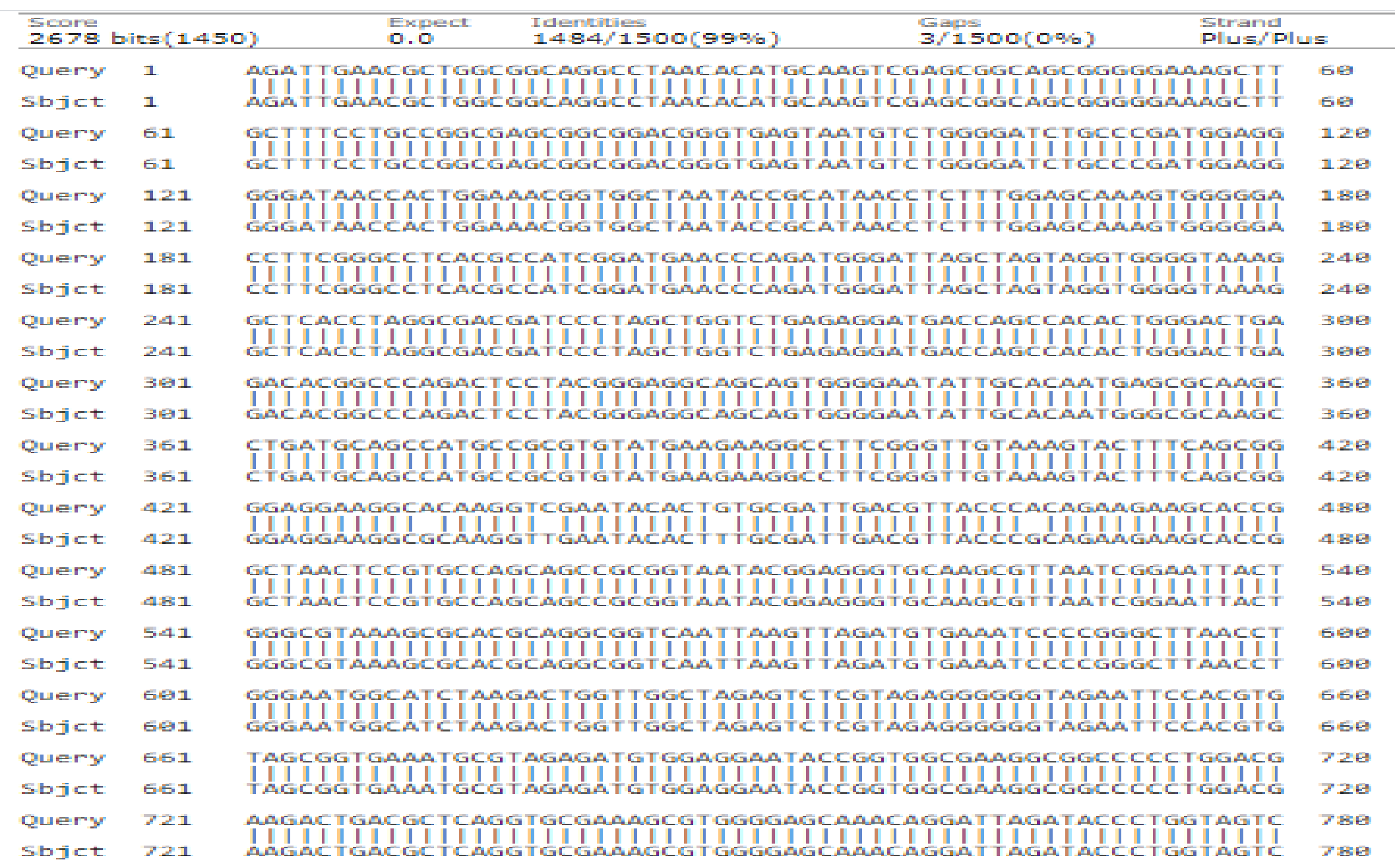




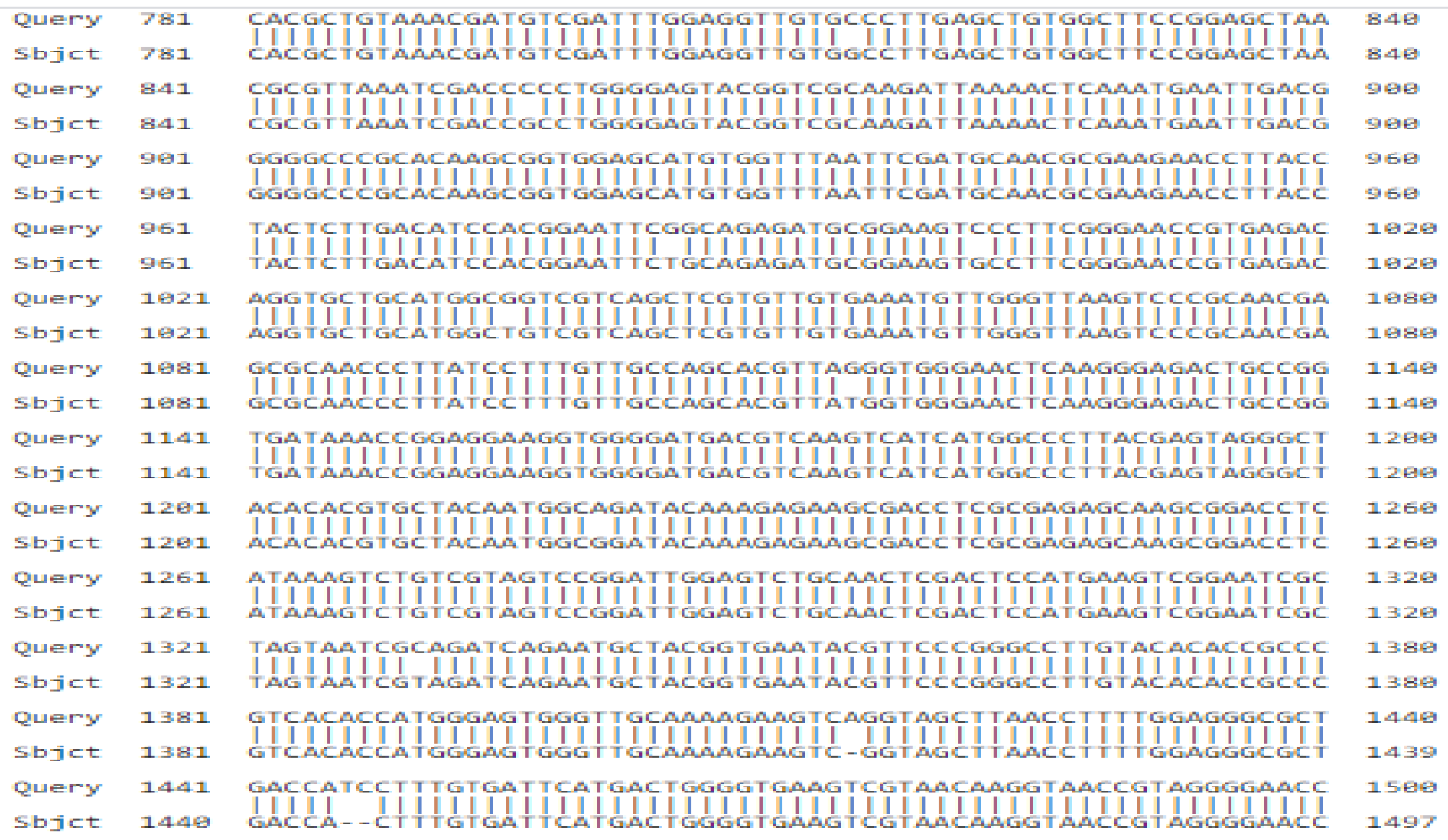

Figure 1. Pairwise sequence alignment of ITS1 region of present Xenorhabdus sp. strain Kalro (MW245845) symbiont bacteria with the most closely related species Xenorhabdus sp. My8NJ. Query= Xenorhabdus sp.strain Kalro (MW245845); Sbjct= Xenorhabdus sp. My8NJ 
Pathogenicity of symbiotic bacteria isolate against Tomato leafminer Tuta absoluta $2^{\text {nd }}$ stage larvae

Pathogenicity of bacteria isolates against $2^{\text {nd }}$ instar larvae of T. absoluta was carried out. The T. absoluta larvae were obtained from a culture maintained on a tomato crop established in a screen house at KALRO-Kandara. Pathogenicity evaluation was according to Yooyangket et al., (2018) method. A single colony of bacteria isolate was inoculated in $3 \mathrm{ml}$ of LB broth and incubated at $30^{\circ} \mathrm{C}$ for $48 \mathrm{~h}$. The bacteria broth culture was centrifuged at $150 \mathrm{rpm}$ and the bacterial pellet was suspended in $1 \mathrm{ml}$ sterile distilled water. Serial dilution of bacterial cell suspension was done resulting in four concentrations; $0.9 \times 10^{9}$, $1,7 \times 10^{9}, 2.6 \times 10^{9}$, and $3.6 \times 10^{9}$, used to evaluate the pathogenicity of the bacteria isolate against the $2^{\text {nd }}$ stage larvae of T. absoluta. The experiment was comprised of five treatments in 5 replicates; control (distilled water), $0.9 \times 10^{9}, 1,7 \times 10^{9}, 2.6 \times 10^{9}$, and $3.4 \times 10^{9} / \mathrm{ml}$ distilled water of bacterial concentrations. Each treatment comprised of 5 larvae individually placed in a petri dish lined with a filter paper thus a total of 25 larvae were used. In each treatment, $1 \mathrm{ml}$ of bacterial cell suspension was dispensed in each Petri dish. Data on T. absoluta mortality was recorded at 24 and $48 \mathrm{~h}$ exposure time.

\section{Data analysis}

The symbiotic bacteria isolate sequence and phylogeny analysis were done using BioEdit v.7.5. and SeaView v.4. Bioinformatics programs. Larval mortality data were subjected to Statistical analysis, Analysis of variance (ANOVA) using Genstat, $15^{\text {th }}$ edition, Statistical software. The means were separated using Fisher's protected least significant difference test at a 5\% significance level.

\section{Results}

Physiological and Biochemical

Microscopy, biochemical and physiological analysis of isolate bacteria is summarized in Table 1

Table 1. Microscopy, biochemical and physiological analysis of isolate bacteria

Microscopy and Biochemical analysis Result

\section{Gram stain}

Colony shape and color

NA

NBTA

MacConkey

Glucose fermentation

Catalase

Urease

Rod-shaped
Convex with irregular edges
Cream White
Dark Blue
Red
+
-
+

$(-)=$ Negative; $(+)=$ Positive; NA=Nutrient agar; NBTA=Nutrient BromoThymol Agar

\section{Sequence and phylogenetic analysis}

The length of the 16S sequence of rDNA obtained from symbiotic bacteria was $1500 \mathrm{bp}$. The BLASTn results of $16 \mathrm{~S}$ rDNA of the symbiotic bacteria had sequence maximum identity/similarity of between 97 and $98.93 \%$, with Xenorhabdus spp retrieved from Genbank. The isolate was closely matched to Xenorhabdus sp. My8NJ with 98.93\% similarity (Accession AB507811.1) isolated from EPN Steinernema sp. MY8, from Japan. Other relatives with a close similarity index to the isolate were; Xenorhabdus ishibishii (AB243427) 98.93\%, X. ishibishii strain GDh7 (NR117216.1) 98.79\%, X. eopokensis DI20 (NR156925.1) 98.06\%, Xenorhabdus sp. GD328 (GQ149085) 98.94\%, X. griffinae ID10 (NR043643.1) 98.04\%, Xenorhabdus sp. VN13 
(FJ51800.1) 97.46\%, X. ehlersii strain DSM (NR042327.1) 97.34\%, X. poinarii strain NC (FJ515806) 97.27\%, and X. thuongxuanensis (NR156924.1) with 97\% identity (Table 2).

Pairwise sequence alignment revealed bacteria

Table 2. Symbiotic bacteria species used in phylogenetic analysis of 165 rDNA of present isolate (Xenorhabdus species)

\begin{tabular}{|c|c|c|c|c|c|c|c|}
\hline $\begin{array}{l}\text { Bacteria isolate } \\
\text { relatives }\end{array}$ & $\begin{array}{l}\text { Sequence } \\
\text { length }\end{array}$ & $\begin{array}{l}\text { Max } \\
\text { Score }\end{array}$ & $\begin{array}{l}\text { Query } \\
\text { Cover }\end{array}$ & $\begin{array}{l}\mathrm{E} \\
\text { value }\end{array}$ & $\begin{array}{l}\% \\
\text { Identity }\end{array}$ & $\begin{array}{l}\text { Accession } \\
\text { No. }\end{array}$ & $\begin{array}{l}\text { Isolate } \\
\text { source }\end{array}$ \\
\hline $\begin{array}{l}\text { Xenorhabdus } \\
\text { sp. MY8NJ }\end{array}$ & 1497 & 2678 & 100 & 0.0 & 98.93 & AB507811.1 & $\begin{array}{l}\text { Steinernema } \\
\text { sp. my8 }\end{array}$ \\
\hline $\begin{array}{l}\text { Xenorhabdus } \\
\text { ishibashii }\end{array}$ & 1537 & 2678 & 100 & 0.0 & 98.93 & $\begin{array}{l}\text { AB243427. } \\
1\end{array}$ & $\begin{array}{l}\text { Steinernema } \\
\text { aciari }\end{array}$ \\
\hline X. ishibashii Gdh7 & 1480 & 2636 & 98 & 0.0 & 98.79 & $\begin{array}{l}\text { NR117216. } \\
1\end{array}$ & $\begin{array}{l}\text { Steinernema } \\
\text { aciari }\end{array}$ \\
\hline X. eopokensis DL20 & 1496 & 2591 & 99 & 0.0 & 98.06 & $\begin{array}{l}\text { NR156925. } \\
1\end{array}$ & $\begin{array}{l}\text { Steinernema } \\
\text { sp. }\end{array}$ \\
\hline $\begin{array}{l}\text { Xenorhabdus sp. } \\
\text { GDC328 }\end{array}$ & 1480 & 2575 & 98 & 0.0 & 98.04 & Gq149085.1 & $\begin{array}{l}\text { Steinernema } \\
\text { leizhouense }\end{array}$ \\
\hline $\begin{array}{l}\text { Xenorhabdus } \\
\text { griffinae IDIO }\end{array}$ & 1473 & 2562 & 98 & 0.0 & 98.04 & $\begin{array}{l}\text { NR043643. } \\
1\end{array}$ & $\begin{array}{l}\text { Steinernema } \\
\text { hermaphroditu } \\
m\end{array}$ \\
\hline $\begin{array}{l}\text { Xenorhabdus } \\
\text { sp.VN13 }\end{array}$ & 2015 & 2555 & 99 & 0.0 & 97.46 & FJ515800.1 & $\begin{array}{l}\text { Steinernema } \\
\text { sp. }\end{array}$ \\
\hline $\begin{array}{l}\text { X. ehlersii strain } \\
\text { Dsm }\end{array}$ & 1524 & 2545 & 100 & 0.0 & 97.34 & $\begin{array}{l}\text { NR042327. } \\
1\end{array}$ & $\begin{array}{l}\text { Steinernema } \\
\text { serratum }\end{array}$ \\
\hline $\begin{array}{l}\text { Xenorhabdus } \\
\text { poinarii NC }\end{array}$ & 2014 & 2540 & 100 & 0.0 & 97.27 & FJ515806.1 & $\begin{array}{l}\text { Steinernema } \\
\text { glasieri }\end{array}$ \\
\hline $\begin{array}{l}\text { Xenorhabdus } \\
\text { thuongxuasensis }\end{array}$ & 1526 & 2534 & 100 & 0.0 & 97.00 & $\begin{array}{l}\text { NR156924. } \\
1\end{array}$ & $\begin{array}{l}\text { Steinernema } \\
\text { sp. }\end{array}$ \\
\hline Escherichia coli & 1541 & & & & & J01859.1 & - \\
\hline
\end{tabular}

The phylogenetic tree constructed using retrieved Xenorhabdus sp. from Genbank is shown in Figure 2. Two major clades of bacteria Xenorhabdus sp. were obtained from the tree. The bacteria isolate clustered in a clade sub-branch with Xenorhabdus sp. My8NJ (AB507811.1), X. isolate close matches in nucleotide bases with symbiotic bacteria Xenorhabdus sp. My8NJ (Figure 1). ishibishii (NR117216), and X. graffinae (NR043643). These were the most convergent Xenorhabdus species to bacteria isolate while $E$. coli (J01859) was most unrelated among the selected bacteria species. 
NJ 1451 sites J-C 1000 repl.

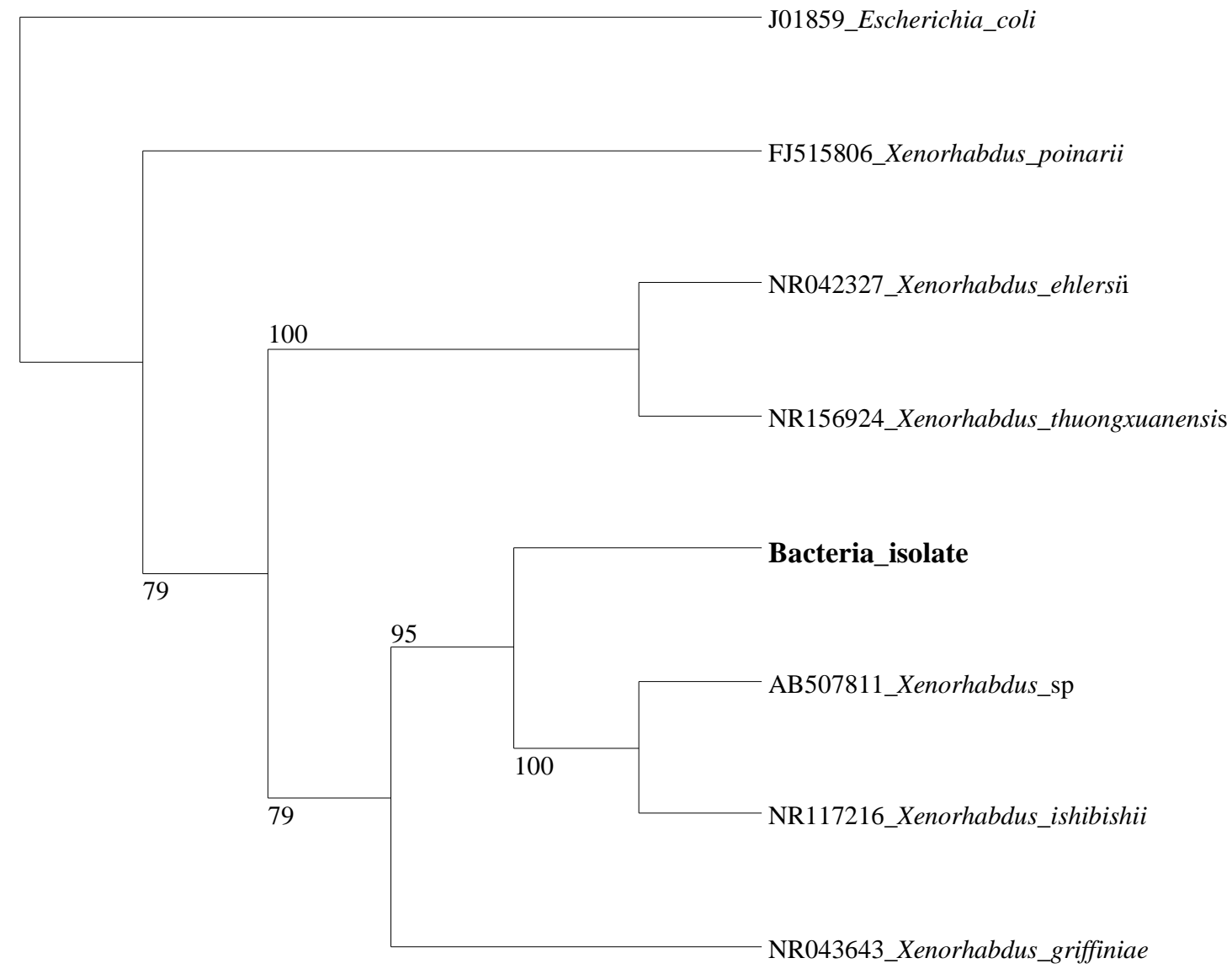

Figure 2. Phylogenetic relationship of bacteria isolate based on $16 S \mathrm{rDNA}$ sequence analysis through Distance Method, Neighbor-Joining

Pathogenicity of bacteria isolate against the $2^{\text {nd }}$ stage larvae of Tuta absoluta under laboratory condition

Larval mortality of Tuta absoluta was observed only in the bacteria treatments over $48 \mathrm{~h}$ of exposure. At $24 \mathrm{~h}$ of exposure, there was no larval mortality recorded in the control experiment. The larval mean mortality of $68 \pm 4.9,84 \pm 4.0,92 \pm 4.9$, and $96 \pm 4.0 \%$, respectively, was observed in bacteria concentrations $0.9 \times 10^{9}, 1,7 \times 10^{9}, 2.6 \times 10^{9}$, and $3.6 \times 10^{9}$ (Figure $3 \mathrm{~A}$ ). There was a significant difference $(\mathrm{P}<0.05)$ between the control and all the other treatments. A significant difference
$(\mathrm{P}<0.05)$ between bacteria concentration $0.9 \times 10^{9}$, $1.7 \times 10^{9}, 2.6 \times 10^{9}$, and $3.6 \times 10^{9}$ was observed.

At $48 \mathrm{~h}$ exposure time mean mortality of $0 \pm 0.0$, $88 \pm 8.0,96 \pm 4.0,96 \pm 4.0$, and $100 \pm 0.0 \%$ was recorded in the control and bacteria concentrations $0.9 \times 10^{9}, 1.7 \times 10^{9}, 2.6 \times 10^{9}$, and 3.6 $\mathrm{x} 10^{9}$ respectively (Figure $3 \mathrm{~B}$ ). There was a significant difference $(\mathrm{P}<0.05)$ between the control and all the treatments but there was no significant difference among the treatments with bacteria. 
$3 \mathrm{~A}$

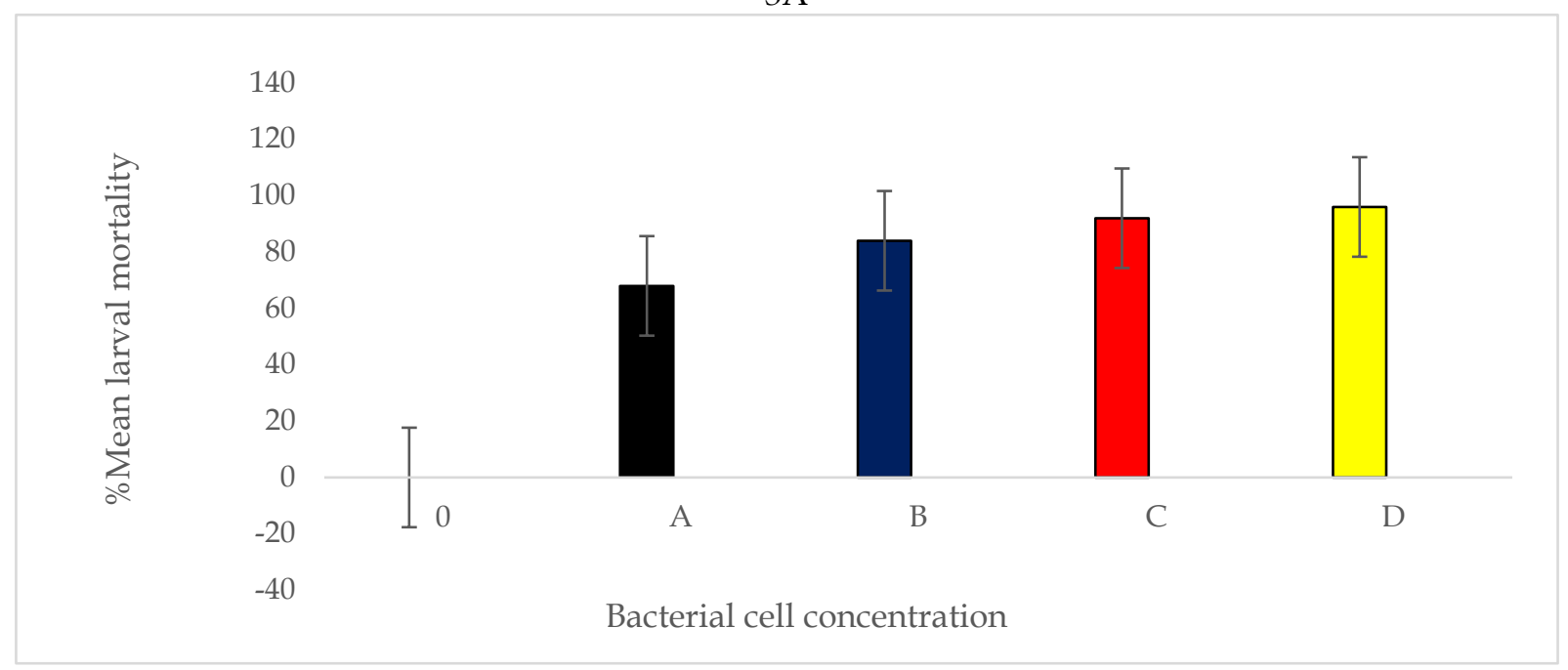

3B

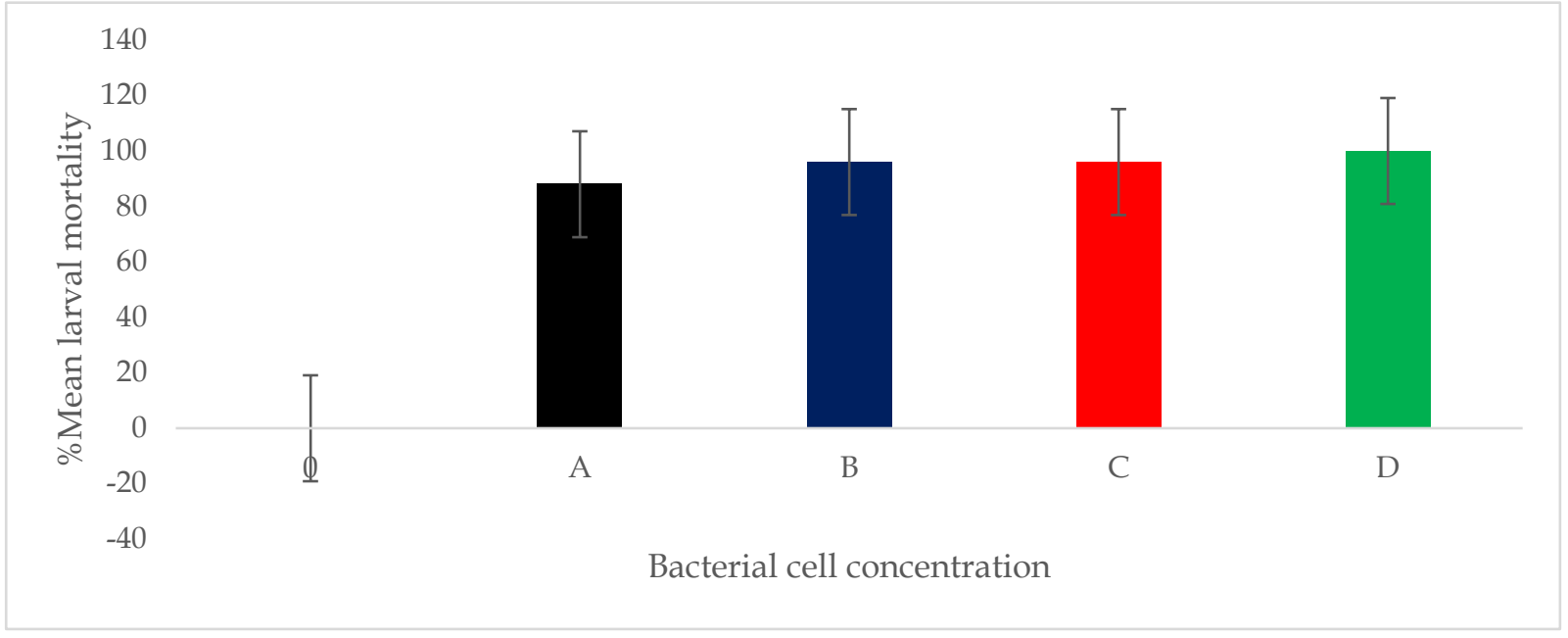

Figure 3. Pathogenicity of bacteria isolate on Tuta absoluta (3A) at $24 \mathrm{~h}$ and (3B) $48 \mathrm{~h}$ exposure $(A)=0.9 \times 10^{9} ;(B)=1,7 \times 10^{9} ;(C)=2.6 \times 10^{9}$ and $(D)=3.6 \times 10^{9}$

\section{Discussion}

Phenotypically isolate symbiont bacterial colonies were creamy white in an appearance on nutrient agar (NA) medium, raised, circular with smooth to irregular edges, shiny, and opaque in appearance. The bacterial cells were also rodshaped and the results conformed to Shields and Cathcart, (2011); Sugar et al., (2012), and Kampfer et al., (2017). The bacteria was Gram-stainnegative as pink coloration was observed as it was unable to retain crystal violet stain (dark blue) suggesting they have a thin cell wall. It is reported that Steinernematidae EPNs harbor mutualistic bacteria, Xenorhabdus spp. that are
Gram-negative (Kumar et al., 2011; Kampfer et al., 2017). The blue bacteria colonies on a clear zone on NBTA indicated bacteria ability to absorb Bromothymol blue dye and reduce Triphenyltrizolium chloride (TTC) in the medium. The growth of red-colored bacterial colonies on the MacConkey medium was an indication the study bacteria were Gramnegative. This is because only Gram-negative bacteria flourish in bile salt in the MacConkey medium absorbing neutral red dye hence red colony appearance (Kumar et al., 2011; Kampfer et al., 2017). Positive glucose fermentation and acid gas production were observed from isolated symbiotic bacteria. This was indicated by gas 
accumulation in Durham tubes and a change in media color from violet/purple to yellow (Kumar et al., 2011). The finding disagrees with Thomas \& Poinar, (1979), who reported glucose and other carbohydrates fermentation without acid gas production from entomopathogenic Xenorhabdus nematophilic bacteria.

The symbiont bacteria was motile confirmed by turbidity observed extending away from the stab line of inoculation. Bacteria motility is a key in the classification and host-pathogen relationship in causing infections (Easom \& Clarke, 2008; Shields \& Cathcart, 2011). The negative catalase results suggested the inability of the bacteria isolate to breaks down $\mathrm{H}_{2} \mathrm{O}_{2}$ into water and Oxygen. A characteristic feature of EPNs symbiotic bacteria Xenorhabdus and Photorhabdus spp. (Kumar et al., 2011; Kampfer et al., 2017). Positive urease reaction was due to the bacteria isolate ability to break down urea into ammonia and carbon dioxide to form ammonium carbonate (alkaline). Ureases in EPNs symbiont bacteria suggest contributing to pathogenic properties of bacteria (Kumar et al., 2011; Salvadori et al., 2012; Lechowicz et al., 2016). The results contradict with Kampfer et al., (2017), who reported negative urease activity EPN symbiotic bacteria Xenorhabdus thuongxuanensis sp.Nov. and Xenorhabdus eapokensis sp.Nov. 6.7.

Molecular identification revealed bacteria isolate was Xenorhabdus species of bacteria which was supported by sequence and phylogeny analysis. The closest relative Xenorhabdus sp. My8NJ (Accession AB507811.1), with 98.93\% similarity had been isolated from EPN Steinernema sp. MY8, from Japan. In addition, the bacteria accessions from Genbank showed geographical relatedness in that most of them had been isolated from EPNs Steinernema sp. from Asia (China, Japan, Indonesia) in origin.

The bacteria isolate was pathogenic against Tuta absoluta as it was able to infect and kill the larvae. This suggested that bacteria isolate overcome $T$. absoluta immune resistance leading to the death of the larvae. It was observed that even outside the EPN vector, bacteria isolate was still lethal to T. absoluta larvae. There is a possibility that the bacterial cells entered the larvae hemocoel through the same natural openings (anus, mouth, spiracles), which are entry points for EPN as reported by Shan et al. (2019). This is the first scientific research report on EPNs symbiotic bacteria pathogenic to T. absoluta larvae in Kenya. However, the larvicidal activity of the EPNs symbiotic bacterial cell suspensions against insect larvae of Diamondback moth (Plutella xylostella), Greater wax moth (Galleria mellonella), and mosquito has been reported (Aedes aegypti and Aedes albopictus) (Vanitha et al., 2010; Vitta et al., 2018; Yooyangket et al., 2018; Salgado-Morales et al., 2019).

There was a varied percentage of larval mortality of $T$. absoluta larvae on exposure to different bacterial cell concentrations over time. There was positive a correlation between bacterial cell concentration and larval mortality hence increased pest knockdown. The results agree with Kalia et al., (2018), who reported mortality of Tobacco cutworm (Spodoptera litura), neonates after $96 \mathrm{~h}$ of exposure to Photorhabdus luminescens bacteria following feeding bioassay.

\section{Conclusion and recommendation}

From the study results, it's concluded that bacteria are mutually associated with EPN Steinernema sp. Kalro (Accession MW151701), is a Xenorhabdus species deposited in Genbank as Xenorhabdus sp. strain Kalro (Accession MW245845). The bacteria are a potential biological control agent against Tuta absoluta larvae. Further classification of the bacteria to species level and pathogenicity trials against $T$. absoluta in the screen house and field are recommended.

\section{Acknowledgment}

We are grateful for the support received from the Kenya Agricultural and Livestock Research Organisation (KALRO) and the University of Nairobi. Also United States Agency for International Development (USAID), Bureau of Food Security under the Cooperative Agreement No. AID-OAA-L-15-00001 as part of Feed the Future Innovation Lab for Integrated Pest Management for the financial support. 


\section{References}

Abdolmaleki, A., Maafi, Z.T., Dastjerdi, H.R., Naseri, B., \& Ghasemi, A. (2016). Isolation and identification of entomopathogenic nematodes and their symbiotic bacteria from Kurdistan province in Iran. Journal of Crop Protection, 5 (2): 259 - 271. DOI:10.18869/modares.jcp.5.2.259

Ahmed, J.M., Azazy, A.M., Abdelall, M.F., Saleh, W.D., \& Ali, M.A. (2018). Phortohubdus and Xenorhabdus for biocontrol of the leafminer, Tuta absoluta. Bioscience Research, 15 (3): 2185 - 2193. http:/ /www.isisn.org/BR15(3)2018/218 5-2193-15(3)2018BR18-323.pdf

Aiswarya, D., Raja, K.R., Gowthaman, G., Deepak, P., Balasubramani, G., \& Perumal, P. (2017). Antibacterial activities of extracellular metabolites of symbiotic bacteria, Xenorhabdus and Photorhabdus isolated from entomopathogenic nematodes. Spring, 3 (2): 80 - 88 .

Akhurst, R. (1980). Morphological and functional dimorphism in Xenorhabdus spp. Bacteria symbiotically associated with the insect pathogenic nematodes Neoaplectana and Heterorhabditis. Journal of General Microbiology, 121: 303-309 https://doi.org/10.1099/00221287-1212-303

Chen, W.P., \& Kuo, T.T. (1993). A simple and rapid method for the preparation of Gram-negative bacteria genomic DNA. Nucleic acid Research, 21 (9): 2260. doi: 10.1093/nar/21.9.2260.

Cruz-Martinez, H., Ruiz-Vega, J., MatadamasOrtiz, P.T., Cortes- Martinez, C.I., \& Rosas-Diaz, J. (2017). Formulation of entomopathogenic nematodes for crop pest control. A review. Plant Protection Science, $53: \quad 15 \quad-24$. https://doi.org/10.17221/35/2016-PPS

Dillman, A.R., \& Sternberg, P.W. (2012). Entomopathogenic nematodes. Current Biology, 22 (11): 430-431. doi: 10.1016/j.cub.2012.03.047

Easom, C.A., \& Clarke, D.J. (2008). Motility is required for the competitive fitness of entomopathogenic Photorhabdus luminescens during insect infection. BMC Microbiology, $\quad 8: \quad 168$. https://doi.org/10.1186/1471-2180-8168

Edgar, R.C. (2004). MUSCLE: Multiple sequence alignment with high accuracy and throughput. Nucleic Acids Research, 32 (5): 1792 1797. https://doi.org/10.1093/nar/gkh340

Ferreira, T., \& Malan, A.P. (2014). Xenorhabdus and Photorhabdus, bacterial symbionts of entomopathogenic nematodes Steinernema and Heterorhabditis and their in vitro liquid mass culture: A Review. African Entomology, 22 (1): 1 - 14. https://doi.org/10.4001/003.022.0115

Gouy, M., Guindon, S., \& Gascuel, O. (2010). SeaView version 4: A multiplatform graphical user interface for sequence alignment and phylogenetic tree building. Molecular Biology and Evolution, $\begin{array}{lllll}27 & \text { (2): } 221 & 224 .\end{array}$ https://doi.org/10.1093/molbev/msp2 59

Hall, T.A. (1999). BioEdit. A user-friendly biological sequence alignment editor and analysis program for Windows 95/98/NT. Nucleic acids symposium series, 41: 95 - 98 . DOI: 10.14601/Phytopathol_Mediterr14998u1.29

Kalia, V., Sharma, G., \& Ganguly, S. (2018). Virulence of native EPN strains and their symbionts alone to polyphagous Lepidopteran pests, visa vis model insect Galleria mellonella along with in vivo production. Entomology, Orthonology Herpetology, 7 (2): 210 - 218. DOI: 10.4172/2161-0983.1000210

Kalia, V., Sharma, G., Shapiro-IIan, D.I., \& Ganguly, S. (2014). Biocontrol potential of Steinernema thermophilum and its symbiont Xenorhabdus indica against Lepidopteran pests: virulence to eggs and larval stages. Journal of Nematology, 46 (1): 18 - 26. PMID: 24643472

Kampfer, P., Tobias, N.J., Ke, L.P., Bode, H.B., \& Glaeser, S.P. (2017). Xenorhabdus thungxuanenseis sp. Nov. and Xenorhabdus eapokensis sp. Nov, isolated from Steinernema spp. International 
Journal of Systemic and Evolutionary Microbiology, 67: 1107 - 1114. DOI: 10.1099/ijsem.0.001770

Kumar, S.V., Mulla, S.R., \& Suresh, C.K. (2011). Isolation and molecular characterization of symbiotic bacterial isolates associated with entomopathogenic nematode in agro climate zone 5 of Karnataka. Journal of Phytology, 3 (11): 25 - 29

Lechowicz, L., Chrapek, M., Czerwonka, G., Korzeniowska-Kowal, A., Tobiasz, A., Urbaniak, M., Matuska-Lyzwa, J., \& Kaca, W. (2016). Detection of ureolytic activity of bacteria strains isolated from entomopathogenic nematodes using infrared spectroscopy. Journal of Basic Microbiology, 56 (8): 922 - 928. https://doi.org/10.1002/jobm.20150053 8

Poinar, G.O., \& Grewal, P.S. (2012). History of entomopathogenic nematology. Journal of Nematology, 44 (2): 153 - 161. PMCID: PMC3578475

Proschak, G.O., Schultz, K., Herrmann, J., Doowlinng, A.J., Brachmann, A.O., Ffrench-Constant, R., Muller, R., \& Bode, H.B. (2011). Cytotoxic fatty acid amides from Xenorhabdus. Chem Bio Chem, 12: 2011 2015. https://doi.org/10.1002/cbic.201100223

Razia, M., Padmanaban, K., Karthik, R.R., Chellapandi, P., \& Sivaramakrishnan, S. (2011). PCR RFLP pattern analysis of entomopathogenic nematodes isolated from agroecosystem for implicating their genetic diversity. Journal of Entomological Zoology, 6 (1): 404 - 411

Salgado-Morales, R., Martinez-Ocampo, F., Obregon-Barboza, V., Vilchis-Martinez, K., Jimenez-Perez, A., \& DantanGonzalez, E. (2019). Assessing the pathogenicity of two bacteria isolated from the entomopathogenic nematode Heterorhabditis indica against Galleria mellonella and some pest insects. Insects, 10 (3): 83. DOI: 10.3390/insects10030083.

Salvadori, J., Defferiari, M., Ligabue-Braun, R., Lau, E., Salvadori, J., \& Carlini, C. (2012). Characterisation of entomopathogenic nematodes and symbiotic bacteria active against Spodoptera frugiperda (Lepidoptera; Noctuidae) and contribution of bacteria urease to insecticidal effect, Biological Control, 63 (3): $253 \quad-\quad 263$. https://doi.org/10.1016/j.biocontrol.20 12.08.002

Sambrook, J., Fristch, E.F., \& Maniatis, T. (1989). Molecular Cloning: A Laboratory Manual (2 ${ }^{\text {nd }}$ ed.). Cold Spring Harbor, NY: Cold Spring Harbor Laboratory Press.

Sangeetha, B.G., Jayaprakas, C.A., Siji, J.V., Rajitha, M., Shyni, B., \& Mohandas, C. (2016). Molecular characterization and amplified ribosomal DNA restriction analysis of entomopathogenic bacteria associated with Rhabditis (Oscheius) spp. Biotechnology, 6 (1): 32 . doi: 10.1007/s13205-015-0326-1

Shan, S., Wang, W., Song, C., Wang, M., Sun, B., Li, Y., Fu, Y., Gu, X., Ruan, W., \& Rasmann, S. (2019). The symbiotic bacteria Alcaligenes faecalis of the entomopathogenic nematodes Oscheius spp. exhibit potential biocontrol of plant and entomopathogenic fungi. Microbial Biotechnology, 12(3): 459 - 471. doi: 10.1111/1751-7915.13365

Shapiro-Ilan, D.I., Cottrel, T.E., Mizel, R.F., Horton, D.L., \& Zaid, A. (2015). Field suppression of the Peach borer, Synathedon exitiosa, using Steinernema carporcapsae: Effect of irrigation, sprayable gel and application method. Biological Control, 82 (2015): 7 - 12. https://doi.org/10.1016/j.biocontrol.20 14.12.003

Shields, P., \& Cathcart, L.A. (2011). Motility test medium protocol. Washington, DC: American Society of Microbiology, pp. 1 - 10.

Sugar, D.R., Murfin, K.E., Chaston, J.M., Andersen, AW., Richards, G.R., DeLeon, L., Baum, J.A., Clinton, W.P., Forst, S., Goldman, B.D., Krasomil-Osterfeld, K.C., Slater, S., Stock, P., \& GoodrichBlair, H. (2012). Phenotypic variation and host variation of Xenorhabdus bovienii SS2004, the entomopathogenic symbiont of Steinernema jollieti nematode. Environmental Microbiology, 14 (4): 924 $939 . \quad$ doi: $10.1111 / \mathrm{j} .1462-$ 2920.2011.02663.x 
Thomas, G.M., \& Poinar Jr. G.O. (1979). Xenorhabdus gen. Nov., a genus of entomopathogenic nematophilic bacteria of family Enterobacteriaceae. International Journal of Systematic Bacteriology, 29 (4): $352 \quad-360$. https://doi.org/10.1099/00207713-29-4352

Ulug, D., Hazir, C., \& Hazir, S. (2015). A new and simple technique for the isolation of symbiotic bacteria associated with entomopathogenic nematodes (Heterorhabditidae and Steinernematidae). Turkish Journal of Zoology, 39: 365 - 367. DOI: 103906/zoo1404-63

Weisburg, W.G., Barns, S.M., Pelletier, D.A., \& Lane, D.J. (1991). 16S Ribosomal DNA amplification for phylogenetic study. Journal of Bacteriology, 173 (2): 697 - 703. DOI: $10.1128 /$ jb.173.2.697-703.1991

Yooyangket, T., Muangpat, P., Polseela, R., Tandhavanant, S., Thanwisal, A., \& Vitta, A. (2018). Identification of entomopathogenic nematodes and symbiotic bacteria from Nam Nao National Park in Thailand and larvicidal activity of symbiotic bacteria against Aedes aegypti and Aedes albopictus. PLOS ONE, 13 (4): p. e019568. DOI: 10.1371/journal.pone.0195681

Zolfagharian, M., Saeedizadeh, A., \& Abbasipour, H. (2016). Efficacy of two entomopathogenic nematodes as potential biocontrol agents against Diamondback moth, Plutella xylostella (L.). Journal of Biological Control, 30 (2): 78 - 83. DOI:10.18311/jbc/30/2/14919
Vanitha, L.S., Kumari, M., Jayappa, J., \& Chandrashekar, S.C. (2010). Symbiotic bacteria, Xenorhabdus spp. of entomopathogenic nematodes: source of antifungal compounds against four plant pathogens. Asian Journal of Bioscience, 5 (2): $174-177$

Vitta, A., Thimpoo, P., Meesil, W., Yimthin, T., Fukruksa, C., Polseela, R., Mangkit, B., Tandhavanant, S., \& Thanwisal, A. (2018). Larvicidal activity of Xenorhabdus and Photorhabdus bacteria against Aedes aegypti and Aedes albopictus. Asian Pacific Journal of Tropical Medicine, 8 (1): 31 - 36. DOI: $10.4103 / 2221-1691.221134$ 